Testicular oocyte development and other toxic effects in the common hourglass tree frog exposed to three commercial insecticide formulations

P. Jeganathan and R.S. Rajakaruna*

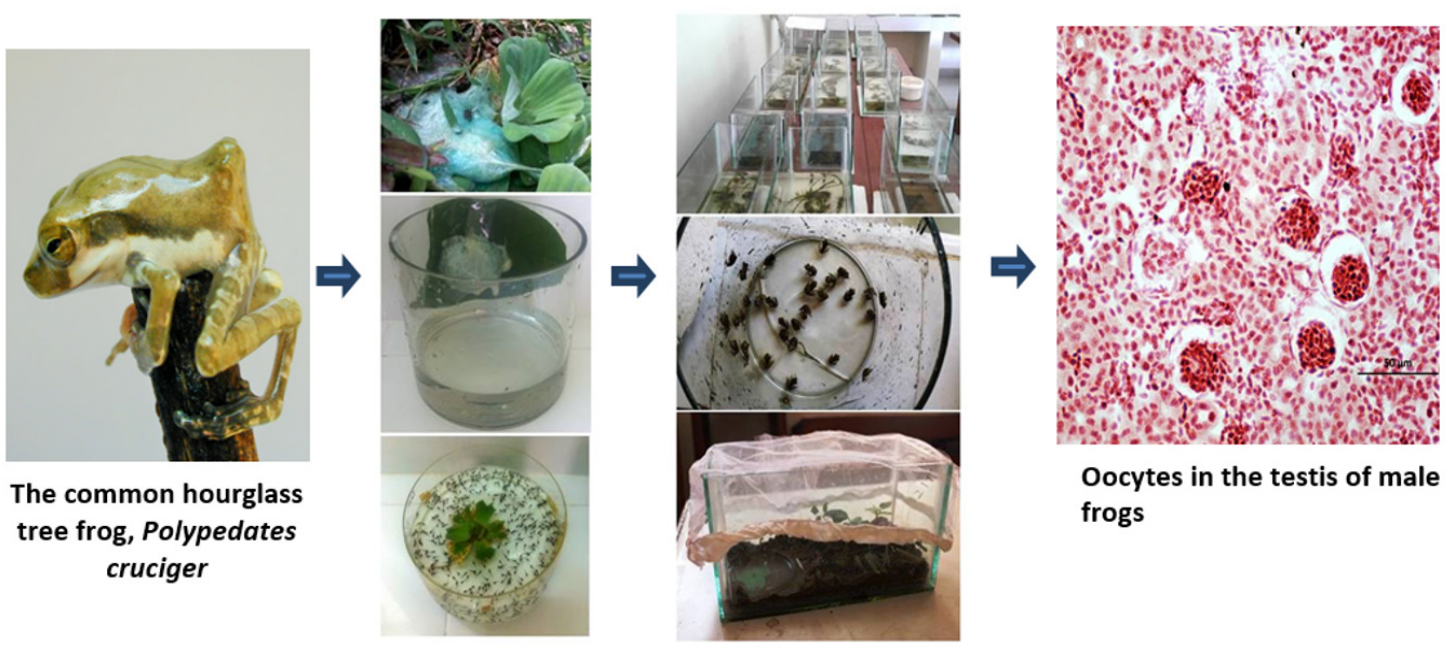

Exposure of tadpoles to insecticides and rearing of metamorphs under laboratory conditions

\title{
Highlights
}

- Profenofos, diazinon and carbosulfan induced development of testicular oocytes in male frogs.

- Acute toxicity in terms of $\mathrm{LC}_{50}$ was highest in profenofos.

- Chronic exposure to field level of three insecticides showed a reduction in survival and affected the growth.

- Insecticide exposed tadpoles were smaller and took a longer time to metamorphose.

- None of the chemicals induced any external malformations. 


\title{
RESEARCH ARTICLE
}

\section{Testicular oocyte development and other toxic effects in the common hourglass tree frog exposed to three commercial insecticide formulations}

\author{
P. Jeganathan ${ }^{1}$ and R.S. Rajakaruna ${ }^{1,2, *}$ \\ ${ }^{1}$ Postgraduate Institute of Science, University of Peradeniya, Peradeniya, Sri Lanka. \\ ${ }^{2}$ Department of Zoology, University of Peradeniya, Peradeniya, Sri Lanka.
}

Received: 10/08/2020; Accepted: 04/08/2021

\begin{abstract}
The endocrine-disrupting effects of insecticides on wildlife have received increasing attention in the literature in recent years. Here we tested the lethal and sub-lethal effects of three commercial insecticide formulations of profenofos, carbosulfan, and diazinon on the common hourglass tree frog, Polypedates cruciger, under laboratory conditions. Acute and chronic exposures to the three chemicals on the survival, growth and development of malformations were studied. The acute toxicity (at Gosner stages 23, 25 - 26, and 31) in terms of $\mathrm{LC}_{50}$ was highest in profenofos followed by diazinon and lowest in carbosulfan. Chronic exposure (at Gosner stage 25) to environmentally relevant concentrations of three insecticides showed a reduction in the survival of the tadpoles. It also affected the growth where the exposed individuals were smaller and took longer to metamorphose than unexposed tadpoles. Histological preparations of the testes of male frogs exposed to all three insecticides developed oocytes, reporting a profound effect in carbosulfan exposure. The concentrations of more than $2 \mathrm{ppb}$ caused oocyte development in $100 \%$ of the exposed frogs. However, none of the chemicals induced any external malformations. These laboratory findings highlight the importance of examining the frogs in chemically contaminated environments for testicular oogenesis,leading to demasculinization of male frogs.
\end{abstract}

Keywords: Testicular ocytes; insecticides; frogs; demasculinization.

\section{INTRODUCTION}

Environmental pollutants can alter the reproduction, growth, and survival of fauna by disrupting the normal functioning of the endocrine system (Pinelli et al., 2019). These endocrine-disrupting compounds (EDCs) are known to interfere with the hormonal functioning of humans and other animals. Many EDCs have anthropogenic sources such as pesticides, industrial effluents, pulp mill effluents, plastics, and sewage. The effects of EDCs in pesticides on wildlife have received increasing attention in the literature during the last decade (Hayes et al., 2010; Skelly et al., 2010; Annamalai and Namasivayam, 2015; Schwindt, 2015; Lifshitz and St Clair, 2016; Pinelli et al., 2019). Skelly et al. (2010) examined 233 frogs in a range of land cover types such as undeveloped, agricultural, suburban, and urban to assess the frequency of amphibian intersex. They found $13 \%$ of all male green frogs (Rana clamitans) have gonads containing testicular oocytes and the frequency was highest $(21 \%)$ in suburban landscapes. Prior to the above study by Skelly et al. (2010), most of the field studies that detected sexual abnormalities in amphibians were conducted with a focus on agricultural land uses (Hayes et al., 2002a,b; Smith et al., 2005; Murphy et al., 2006; McCoy et al., 2008; McDaniel et al., 2008). Many studies have examined the intersex frogs linking abnormal sexual development after exposure to herbicide atrazine (Hayes et al., 2002a, 2003). These studies include reduced testicular volume, germ cells, Sertoli cells (Tavera-Mendoza et al., 2002), and testosterone (Hayes et al., 2002a), induced hermaphrodisim (Hayes et al., 2002a; Carr et al., 2003; Hayes et al., 2006) and testicular oogenesis (Hayes et al., 2002b, 2006; Orton et al., 2006), complete feminization and chemical castration (Hayes et al., 2010), an altered male mating signal expression such as ornamentation and mating behaviours (Solomon et al., 2008; Lifshitz and St Clair, 2016). Tadpoles of Rana dalmatina exposed to chlorpyrifos at ecologically relevant concentrations $(0.025$ and $0.05 \mathrm{mg} / \mathrm{L}$ ) significantly affect gonadal differentiation in some animals by inducing an intersex condition and alterations to testicular morphology (Bernabo et al., 2011). Histologically examined gonads and kidneys of newly metamorphosed wild-caught Oregon Spotted Frog (Rana pretiosa) reported the development of oocytes in the testes of five out of the 11 newly metamorphosed male frogs examined (Griffing et al., 2017).

The present study assessed the lethal and sublethal effects of exposure to commercially available formulations of three insecticides profenofos, carbosulfan, and diazinon at environmentally relevant doses in the tadpoles of the common hourglass tree frog, Polypedates cruciger. This arboreal frog species is a widely distributed endemic amphibian species found throughout Sri Lanka up to 1,525 m, mean sea level (Manamendra-Arachci and Dutta, 1996). It is listed as a Least Concern (LC; IUCN, 2018) species inhabiting secondary forests and anthropogenic habitats with a stable population making it convenient to use as a model organism for scientific research. It lays eggs in a foamy nest that is attached to vegetation overhanging pools and ponds. These eggs hatch about five days after 
laying, and the tadpoles fall into the water body underneath (Manamendra-Arachci and Dutta, 1996). This species is associated with agricultural habitats with a high potential of exposure to many agricultural insecticides in their natural habitat. The objective of the present study is to investigate the acute and chronic effects of exposure of profenofos, carbosulfan, and diazinon on tadpole stages of $P$. cruciger.

\section{MATERIALS AND METHODS}

\section{Test chemicals}

Among the three insecticides tested, profenofos (500 g/L EC; O-4-bromo-2-chlorophenyl O-ethyl S-propyl phosphorothioate) and diazinon (500 g/L EW/EC; O,O-diethylO-2-isopropyl-6-methylpyrimidin-4-yl phosphorothioate) are widely used organophosphorous insecticides whereas carbosulfan (200 g/L SC; 2, 3-dihydro-2, 2-dimethyl benzofuran-7-yl methylcarbamate) is a carbamate. Samples of commercial formulations were obtained from the Pesticide Registrar's Office, Peradeniya, Sri Lanka. Each insecticide was diluted in dechlorinated tap water as indicated in the instruction label on the insecticide bottle, and a dilution series was prepared.

\section{Study animals}

Polypedates is one of the major genera in the Family Rhacophoridae represented by five species, including $P$. cruciger, an endemic tree frog with an island-wide distribution (Manamendra-Arachci and Dutta, 1996). This frog species is primarily associated with humanmodified habitats. It has expanded its natural ranges establishing a higher relative dominance following habitat disturbances as the most threatened species by land and water agrochemical pollution (IUCN, 2004). Foamy egg masses of newly spawned of $P$. cruciger were collected from small ponds and pools in Royal Botanical Gardens in Peradeniya, Sri Lanka from October to December 2013, brought to the lab. Upon hatching, the tadpoles were transferred into glass tanks (measuring $25 \mathrm{~cm} \times 15 \mathrm{~cm} \times 15 \mathrm{~cm}$ ), and fed with commercial fish feed and boiled lettuce three times a day and reared until they were used in insecticide exposures. Ethical clearance for study protocol was obtained from the Ethical Review Committee of the Postgraduate Institute of Science, University of Peradeniya, Sri Lanka.

\section{Acute exposure to determine the $\mathrm{LC}_{50}$ values}

Lethal concentrations of the chemicals which kill 50\% of the populations $\left(\mathrm{LC}_{50}\right)$ was determined by exposing three stages of tadpoles i.e. Gosner 23, 25-26 and 31 (Gosner, 1960). Dilution series were prepared using a commercially available form of the insecticides in dechlorinated tap water after preliminary range-finding exposures (Table1). Dechlorinated tap water was used as the control. Pooled eggs from three clutches were used and 20 tadpoles were placed in a glass tank containing $2 \mathrm{~L}$ of the test solution and the experiment was carried out in replicates. Mortality in each tank was recorded at $24 \mathrm{~h}, 48 \mathrm{~h}$, and $96 \mathrm{~h}$ after exposure. The concentration series for the three chemicals are given in Table 1 .

\section{Chronic exposure to ecologically relevant doses}

Tadpoles from three pooled eggs clutches were raised until Gosner stage 25. Based on the field application values given by the Pesticide Registrar's Office (Peradeniya),

Table 1: Concentration series of insecticides used to determine at $24 \mathrm{~h}, 48 \mathrm{~h}$ and $96 \mathrm{~h} \mathrm{LC}$ for three Gosner stages of tadpoles of Polypedates cruciger ( $n=2,160$ tadpoles).

\begin{tabular}{|c|c|c|c|c|}
\hline \multirow{2}{*}{ Insecticide } & \multirow{2}{*}{ Gosner stage } & \multicolumn{3}{|c|}{$\begin{array}{c}\text { Concentration series } \\
(\mathrm{mg} / \mathrm{L})\end{array}$} \\
\hline & & $24 \mathrm{~h}$ & $48 \mathrm{~h}$ & $96 \mathrm{~h}$ \\
\hline \multirow{3}{*}{ Profenofos } & 23 & $\begin{array}{c}0.900,1.000,1.200 \\
1.300\end{array}$ & $\begin{array}{c}0.600,0.615,0.630 \\
0.645\end{array}$ & $\begin{array}{c}0.400,0.450,0.500 \\
0.550\end{array}$ \\
\hline & $25-26$ & $\begin{array}{c}2.250,2.500,2.750 \\
3.000\end{array}$ & $\begin{array}{c}1.000,1.100,1.200 \\
1.300\end{array}$ & $\begin{array}{c}0.200,0.250,0.300 \\
0.350\end{array}$ \\
\hline & 31 & $\begin{array}{c}5.500,6.000,6.500 \\
7.000\end{array}$ & $\begin{array}{c}3.000,3.250,3.500 \\
3.750\end{array}$ & $\begin{array}{c}0.500,0.600,0.700 \\
0.800\end{array}$ \\
\hline \multirow{3}{*}{ Diazinon } & 23 & $9.5,10.0,10.5,11.0$ & $6.5,7.0,7.5,8.0$ & $2.5,3.0,3.5,4.0$ \\
\hline & $25-26$ & $\begin{array}{c}12.25,12.50,12.75 \\
13.00\end{array}$ & $9.0,9.5,10.0,10.5$ & $5.0,5.5,6.0,6.5$ \\
\hline & 31 & $30.0,30.5,31.0,31.5$ & $23.0,23.5,24.0,24.5$ & $13.0,14.0,15.0,16.0$ \\
\hline \multirow{3}{*}{ Carbosulfan } & 23 & $19.0,20.0,21.0,22.0$ & $13.0,14.0,15.0,16.0$ & $9.0,10.0,11.0,12.0$ \\
\hline & $25-26$ & $24.0,24.5,25.0,25.5$ & $17.0,17.5,18.0,18.5$ & $14.0,14.5,15.0,15.5$ \\
\hline & 31 & $38.0,39.0,40.0,41.0$ & $30.0,32.0,34.0,36.0$ & $17.0,17.5,18.0,18.5$ \\
\hline
\end{tabular}

Note: Above concentrations were selected after preliminary exposures to range finding experiments. 
the concentration series of the three insecticides were selected as follows: profenosfos at $0.125,0.250,0.500$, and $1.000 \mathrm{ppb}$; diazinon at $0.375,0.750,1.500$, and $3.000 \mathrm{ppb}$ and carbosulfan at 1.5, 2.0, 2.5, and $3.0 \mathrm{ppb}$. The exposure was carried out in a similar set of glass tanks used for acute exposures containing $2 \mathrm{~L}$ of the test solutions. The experiment was initiated with 20 tadpoles per tank and dechlorinated tap water was used as the control. The debris and faeces that collected at bottom of the tank were siphoned out and the medium was renewed completely once a week. Each time when the medium was changed, the tanks were rotated around the rack to avoid the position effects. The tadpole survival and development of malformations were observed daily. The snout to vent length (SVL) to the nearest $0.01 \mathrm{~cm}$ was measured and the bodyweight to the nearest $0.001 \mathrm{~g}$ was measured at Gosner stages 27 and 31 . The time required for the forelimb emergence in half the number of tadpoles was recorded as $\mathrm{TE}_{50}$. After metamorphosis, frog-lets were raised in glass tanks containing natural leafy matters to provide a natural moist habitat until Gosner stage 42. They were fed with fruit flies and termites twice a day.

\section{Histological preparations of gonads}

Froglets at Gosner stage 42 were euthanized using MS222 and fixed in Bouin's. Their gonads were dissected out and the left gonad of each animal was dehydrated using a standard ethanol series and then embedded in paraffin wax. Transverse sections (thickness $7 \mu \mathrm{m}$ ) of the gonads were slide mounted, stained with Harris' haematoxylin and eosin and examined under the light microscope.

\section{Statistical analysis}

The $\mathrm{LC}_{50}$ values were calculated with $95 \%$ confidence limits using Log Probit analysis. In the chronic exposure, the effect of concentration of each insecticide on the survival of the tadpoles was analysed using a linear regression. The mean reduction in survival of tadpoles at each concentration was compared with the control using a chi-square test. The relationship of growth parameters: body weight, SVL, and $\mathrm{TE}_{50}$ values and the percentage malformation with the insecticide concentration were analysed using linear regression. The difference in growth parameters between insecticides was compared using an analysis of variance (ANOVA). The individual effect between the insecticides and the control was analysed using Tukey's post-hoc test. The sex ratios of the adult frogs at Gosner stage 42 were compared to an expected 50:50 (male: female) ratio using an observed-versus-expected chi-square test.

\section{RESULTS}

\section{Acute insecticide exposure values $\left(\mathrm{LC}_{50}\right)$}

The $\mathrm{LC}_{50}$ values (with $95 \%$ confidence limits) of $24 \mathrm{~h}, 48$ h, and $96 \mathrm{~h}$ exposures at Gosner stages 23, 25 - 26, and 31 of $P$. cruciger $(n=100$ for each tadpole stage and for each insecticide) for the three insecticides are given in Table 2. The acute toxicity was highest in profenofos followed by diazinon and least in carbosulfan. The younger tadpoles (at Gosner stage 23) were the most sensitive, showing high mortality which decreased with increasing age at exposures from Gosner stage 23 to 31 (Table 2). .

\section{Chronic exposure}

\section{Lethal effects of the chemicals}

The survival of tadpoles in control was $100 \%$ at 10 days posthatch and $95 \%$ at both 30 days post-hatch and metamorphs. Tadpoles and metamorphs in all the exposed groups had lower survival than the control. The percentage survival decreased with increasing concentration of the insecticide (Figure 1). The carbosulfan exposed tadpoles did not show an association between the concentration and survival at 10

Table 2: The $\mathrm{LC}_{50}$ values of profenofos, diazinon, and carbosulfan obtained for different developmental stages of the common hourglass tree frog, Polypedates cruciger at (A) Gosner stage 23 (B) Gosner stage 25 - 26, and (C) Gosner stage 31.

\begin{tabular}{|c|c|c|c|c|}
\hline \multirow{2}{*}{ Insecticide } & \multirow{2}{*}{ Gosner stage } & \multicolumn{3}{|c|}{$\begin{array}{c}\text { Mean } \mathrm{LC}_{50} \text { values } \\
\text { (Range) }\end{array}$} \\
\hline & & $24 \mathrm{~h}$ & $48 \mathrm{~h}$ & $96 \mathrm{~h}$ \\
\hline \multirow{3}{*}{ Profenofos } & 23 & $1.25(0.43-1.33)$ & $0.64(0.25-0.74)$ & $0.51(0.19-0.57)$ \\
\hline & $25-26$ & $2.85(1.04-3.16)$ & $1.29(0.46-1.38)$ & $0.341(0.10-0.34)$ \\
\hline & 31 & $6.69(2.50-7.50)$ & $3.61(1.35-4.05)$ & $0.73(0.25-0.79)$ \\
\hline \multirow{3}{*}{ Diazinon } & 23 & $10.44(4.15-12.25)$ & $7.06(2.92-8.68)$ & $3.71(1.24-3.96)$ \\
\hline & $25-26$ & $12.95(5.15-15.05)$ & $10.33(3.95-11.65)$ & $5.99(2.29-6.91)$ \\
\hline & 31 & $31.41(12.54-36.66)$ & $24.22(9.68-28.32)$ & $15.82(5.83-17.37)$ \\
\hline \multirow{3}{*}{ Carbosulfan } & 23 & $21.82(8.30-24.50)$ & $15.27(5.83-17.37)$ & $11.31(4.17-12.63)$ \\
\hline & $25-26$ & $25.41(10.09-29.51)$ & $18.17(7.22-21.18)$ & $15.33(6.00-17.60)$ \\
\hline & 31 & $40.66(16.09-47.11)$ & $34.65(13.32-39.48)$ & $18.33(7.22-21.18)$ \\
\hline
\end{tabular}

Note: The mortality data was analysed by Log Probit at 95\% confidence interval. The values within the brackets represent the lower and upper limits of the values with respect to the lethal level. 

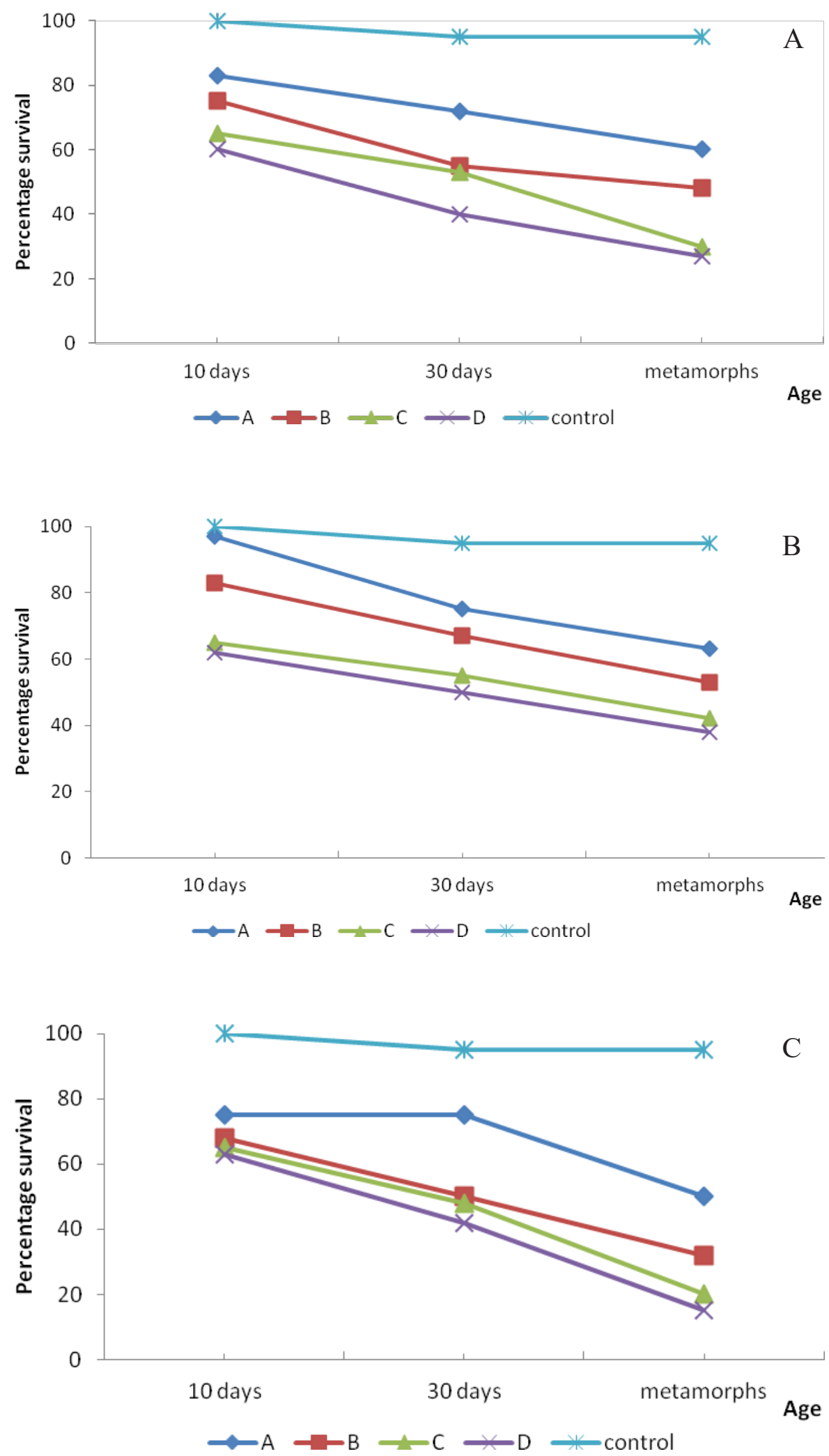

Figure 1: Percentage survival of tadpoles of Polypedates cruciger exposed to three insecticides at different concentrations and control. (1) Profenosfos $\mathrm{A}=0.125, \mathrm{~B}=0.250, \mathrm{C}=0.500, \mathrm{D}=1.000$, (2) Diazinon; $\mathrm{A}=0.375, \mathrm{~B}=0.750, \mathrm{C}=1.5, \mathrm{D}=3.0$, (3) Carbosulfan; $\mathrm{A}=1.5, \mathrm{~B}=2.0, \mathrm{C}=2.5, \mathrm{D}=3.0 . \mu \mathrm{g} / \mathrm{L}$. 
Table 3: Mean Snout-to-vent length (SVL) and mean weight at metamorphosis exposed to field concentrations of pesticides compared to the control using one-way ANOVA.

\begin{tabular}{|c|c|c|c|c|c|c|c|}
\hline Insecticide & $\begin{array}{l}\text { Conc/ } \\
\text { ppb }\end{array}$ & $\begin{array}{l}\text { SVL } \pm \text { SD } \\
\quad(\mathbf{m m})\end{array}$ & $\mathbf{F}$ & $\mathbf{p}$ & $\begin{array}{c}\text { Weight } \pm \text { SD } \\
\text { (g) }\end{array}$ & $\mathbf{F}$ & $\mathbf{p}$ \\
\hline \multirow{4}{*}{ Profenofos } & 0.125 & $7.70 \pm 0.27$ & 9.37 & $0.038^{*}$ & $0.80 \pm 0.01$ & 24.12 & $0.008^{*}$ \\
\hline & 0.250 & $6.32 \pm 0.91$ & 16.70 & $0.015^{*}$ & $0.70 \pm 0.01$ & 82.88 & $0.001 *$ \\
\hline & 0.500 & $6.35 \pm 1.34$ & 11.30 & $0.028 *$ & $0.71 \pm 0.02$ & 59.93 & $0.001 *$ \\
\hline & 1.000 & $6.05 \pm 0.65$ & 24.39 & $0.008^{*}$ & $0.67 \pm 0.02$ & 89.97 & $0.001 *$ \\
\hline \multirow{4}{*}{ Diazinon } & 0.375 & $6.92 \pm 0.56$ & 15.11 & $0.018^{*}$ & $0.81 \pm 0.04$ & 10.76 & $0.030^{*}$ \\
\hline & 0.750 & $6.90 \pm 0.36$ & 17.44 & 0.014* & $0.81 \pm 0.05$ & 11.24 & $0.028 *$ \\
\hline & 1.500 & $6.11 \pm 0.84$ & 20.16 & $0.021^{*}$ & $0.65 \pm 0.11$ & 14.15 & $0.020^{*}$ \\
\hline & 3.000 & $6.07 \pm 0.07$ & 32.00 & $0.005^{*}$ & $0.63 \pm 0.03$ & 95.15 & $0.001 *$ \\
\hline \multirow{4}{*}{ Carbosulfan } & 1.5 & $7.93 \pm 0.08$ & 7.77 & $0.049 *$ & $0.64 \pm 0.04$ & 74.88 & $0.001 *$ \\
\hline & 2.0 & $7.27 \pm 0.51$ & 12.01 & $0.026^{*}$ & $0.65 \pm 0.07$ & 35.35 & $0.004 *$ \\
\hline & 2.5 & $6.30 \pm 0.53$ & 22.94 & $0.009^{*}$ & $0.63 \pm 0.00$ & 157.97 & $<0.001^{* *}$ \\
\hline & 3.0 & $5.42 \pm 0.50$ & 32.28 & 0.004* & $0.60 \pm 0.01$ & 183.32 & $<0.001^{* *}$ \\
\hline Control & 0.00 & $9.73 \pm 1.12$ & - & - & $0.91 \pm 0.04$ & - & - \\
\hline
\end{tabular}

Note: Data represents mean \pm SD from replicates. * denotes significant at $p<0.05 ; * *$ denotes significant at $p<0.001$.

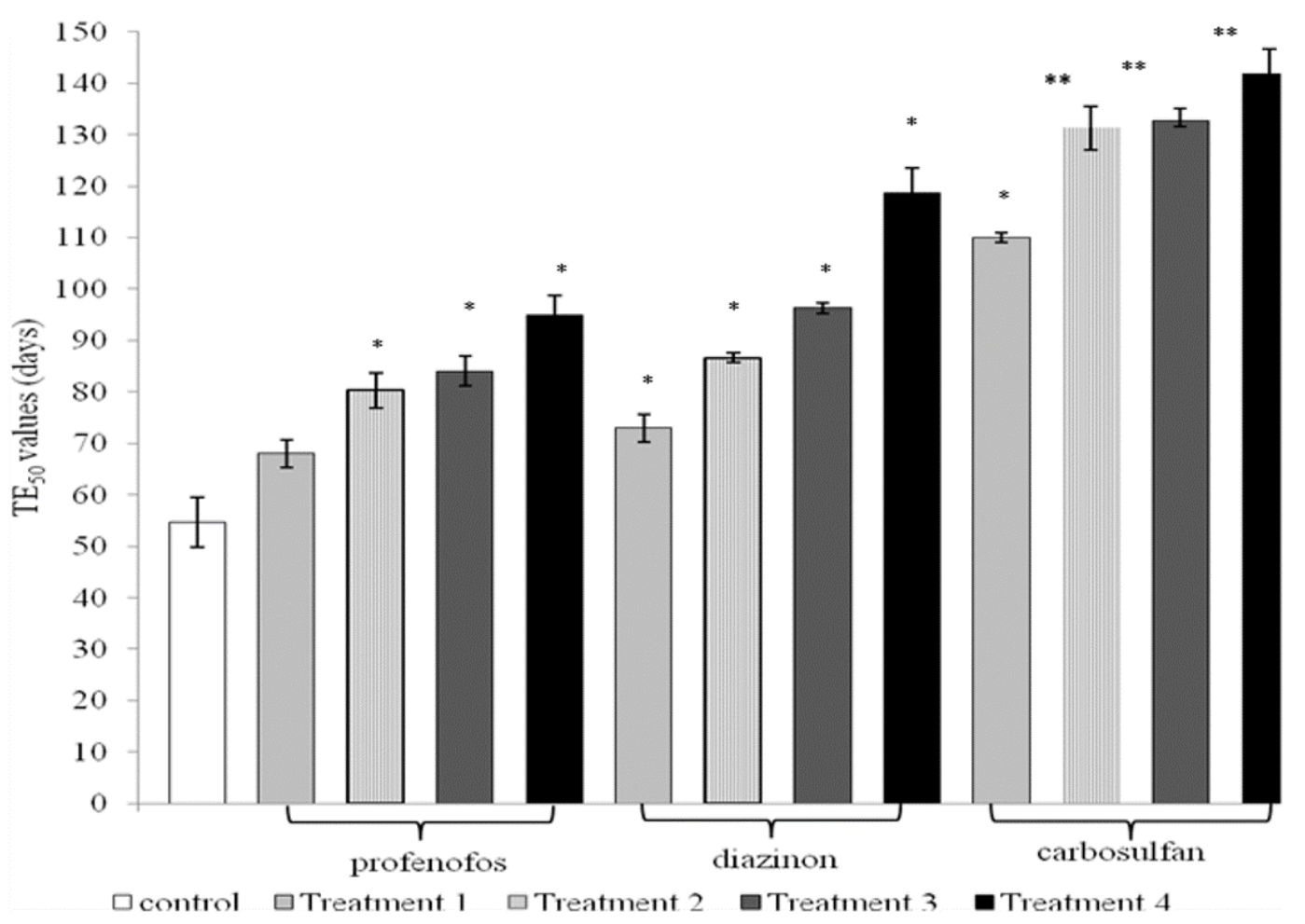

Figure 2: Mean number of days taken for forelimb emergence of half the number of tadpoles $\left(\mathrm{TE}_{50}\right)$ of Polypedates cruciger exposed to three insecticides at different concentrations. Profenosfos: $1=0.125,2=0.250,3=0.500,4=1.000$; Diazinon: $1=0.375,2=0.750$, $3=1.5,4=3.0$; Carbosulfan: $1=1.5,2=2.0,3=2.5,4=3.0$. *denotes significant at $p<0.05 ; * *$ denotes significant at $p<0.001$. 
days post-hatch tadpoles (Linear Regression; $R^{2}=89.1, p=$ 0.056 ) but the metamorphs showed a significant association (Linear Regression; $R^{2}=92.0, p=0.041$ ). However, the reduction in survival was not significant in the tadpoles or metamorphs exposed to profenofos $\left(R^{2}=52.6, p=0.275\right)$ or diazinon $\left(R^{2}=81.8, p=0.96\right)$. Individual comparisons of the survival of tadpoles in each concentration of insecticide with the control showed a significant difference in all the concentrations (Chi-square test; $p<0.01$ ) except in the lowest concentration of profenofos $(0.125 \mathrm{ppb})$ in both 10 days (Chi-square test; $\chi^{2}=1.026, p<0.05$ ) and 30 days of post-hatch tadpoles $\left(\chi^{2}=3.137, p=0.077\right), 0.250 \mathrm{ppb}$ at 10 days post-hatch tadpoles $\left(\chi^{2}=3.243, p=0.072\right)$ and diazinon lowest concentration $(0.375 \mathrm{ppb})$ at 10 days post-hatch tadpoles $\left(\chi^{2}=3.243, p=0.071\right)$ where there was no significant reduction in survival compared to the control. The survival of metamorphs from Gosner stage 31 to 42 declined significantly with increasing insecticide concentrations compared to the control (Chi-square test; $p<$ 0.001; Table 3). Among the three insecticides, carbosulfan exposed frogs had the highest reduction in survival in all the concentrations (Table 3). Correspondingly, the percentage survival decreased with increasing concentration of carbosulfan (Linear Regression; $R^{2}=94.2 \% ; F=32.36, p$ $=0.030)$ but not in profenofos $\left(R^{2}=80.5 \% ; F=8.23, p=\right.$ $0.103)$ or diazinon $\left(R^{2}=76.9 \%, F=6.65, p=0.123\right)$.

\section{Sub-lethal effects of the chemical}

None of the tadpoles or metamorphs developed any external malformations in the exposed or control groups.

\section{Growth of tadpoles}

The tadpoles and metamorphs in the exposed groups were smaller than those of the control. A significant reduction in the weight was observed at metamorphosis with the increasing concentration of all the insecticides (Regression analysis; $p<0.05)$. The individual comparisons of the growth of the exposed metamorphs and those of the control groups showed significant differences in all the treatments (Table 3; One-way ANOVA, Tukey's post-hoc test, $p<$ $0.05)$. The mean $\mathrm{TE}_{50}$ value for unexposed $P$. cruciger was 55 days (52 - 56 days). At the same time, in the exposed groups, it exceeded 68 days in the lowest concentration of profenofos and 142 days in the highest concentration of carbosulfan (Figure 2). This lengthening of the development period was significant in all the exposures compared to the control (One-way ANOVA, $p<0.05$ ) except in the lowest concentration $(1.5 \mathrm{ppb})$ of profenofos.

\section{Sex ratio and gonadal histology}

The male-to-female sex ratio of the unexposed tadpoles in the control setup was $1: 1$, but none of the exposed groups had this ratio (Table 4). Among the three insecticides, a significantly higher number of individuals exposed to diazinon and carbosulfan metamorphosed as males (Chisquare test, $p<0.05$ ). The percentage incidence of males having oocytes increased with the concentration of the insecticides. Carbosulfan recorded the highest number of males having multiple oocytes compared to the other two insecticides, even at low concentrations (Table 4).

Table 4: Percentage survival, sex ratio and percentage of males developed testicular oocytes of Polypedates cruciger exposed to ecologically relevant concentrations of the three chemicals and the control $(n=152)$.

\begin{tabular}{|c|c|c|c|c|c|}
\hline \multirow{2}{*}{ Pesticide } & \multirow{2}{*}{ Conc. $\mu \mathrm{g} / \mathrm{L}$} & \multicolumn{2}{|c|}{ Survival (\%) } & \multirow{2}{*}{$\begin{array}{c}\text { Sex ratio at } \\
\text { Gosner stage } \\
42 \\
\text { Male: Female }\end{array}$} & \multirow{2}{*}{$\begin{array}{c}\text { Males having } \\
\text { oocytes (\%) }\end{array}$} \\
\hline & & Gosner stage 31 & Gosner stage 42 & & \\
\hline \multirow{4}{*}{ Profenofos } & 0.125 & $63.3^{*}$ & $35.0 *$ & $1: 2$ & 50.0 \\
\hline & 0.250 & $53.3^{*}$ & $28.3^{*}$ & $2: 1$ & 60.0 \\
\hline & 0.500 & $41.7^{*}$ & $18.3^{*}$ & $3: 1$ & 87.5 \\
\hline & 1.000 & $38.3^{*}$ & $11.7^{*}$ & $1: 2$ & 100 \\
\hline \multirow{4}{*}{ Diazinon } & 0.375 & $60.0^{*}$ & $25.0 *$ & $5: 1$ & 00.0 \\
\hline & 0.750 & $48.3^{*}$ & $20.0^{*}$ & $2: 1$ & 37.5 \\
\hline & 1.500 & $30.0 *$ & $10.0^{*}$ & $1: 2$ & 100 \\
\hline & 3.000 & $26.7 *$ & $06.7^{*}$ & $4: 0$ & 50.0 \\
\hline \multirow{4}{*}{ Carbosulfan } & 1.50 & $50.0 *$ & $21.7 *$ & $1: 2$ & 75.0 \\
\hline & 2.00 & $31.7^{*}$ & $20.0^{*}$ & $5: 1$ & 100 \\
\hline & 2.50 & $20.0 *$ & $10.0 *$ & $2: 1$ & 100 \\
\hline & 3.00 & $15.0^{*}$ & $03.3^{*}$ & $2: 0$ & 100 \\
\hline Control & - & 95.0 & 91.7 & $1: 1$ & 00.0 \\
\hline
\end{tabular}

Note: Initial number of tadpoles $=20$ per tank. $*$ indicate significantly different compared to the control Chi square test; $p<0.001$. 


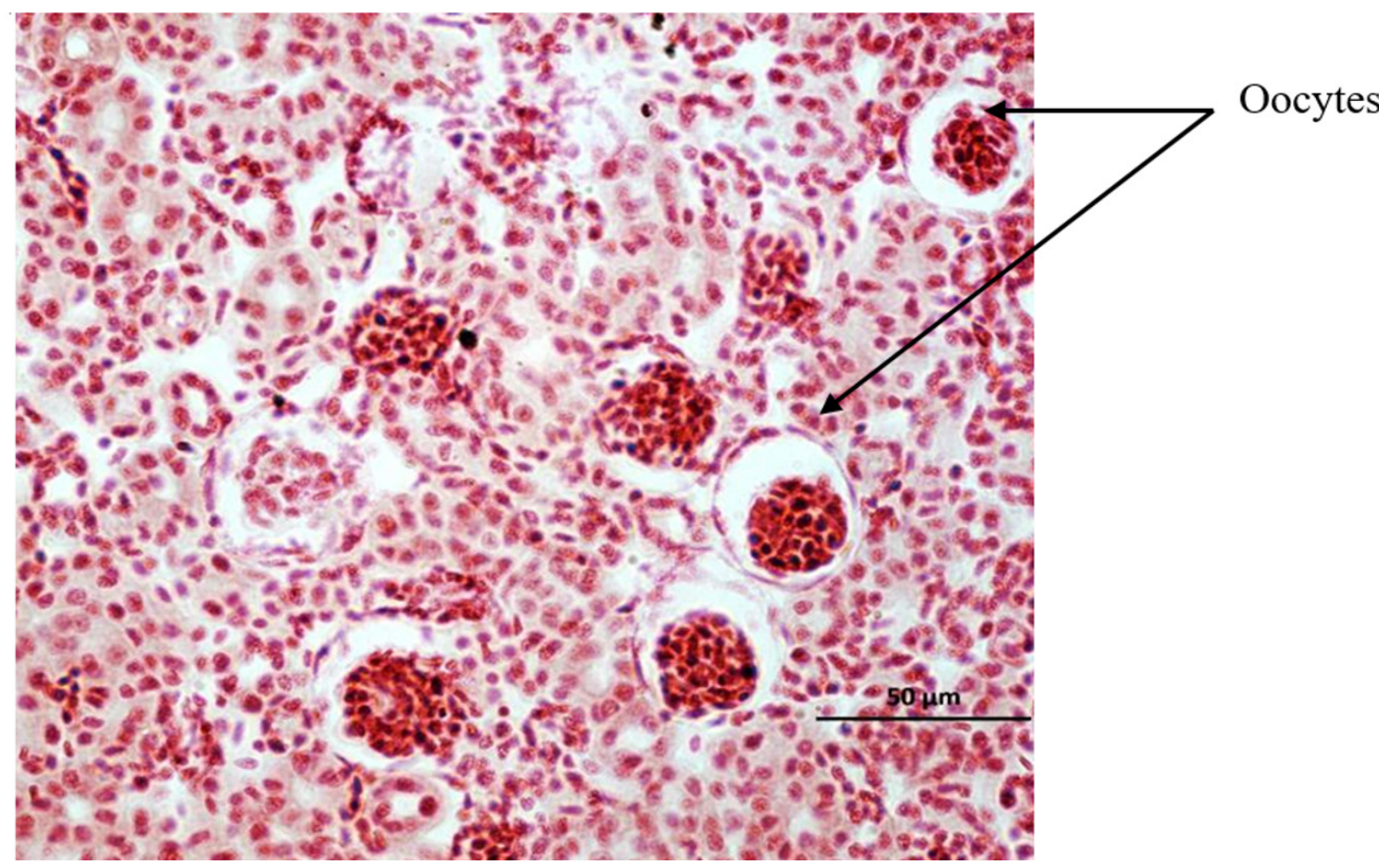

Figure 3: Histological preparations of testes of male frogs of $P$. cruciger at Gosner stage 42 exposed to carbosulfan. Multiple oocytes surrounded by follicle cells with seminiferous tubules are shown by arrows.

Among the metamorphs that reached the adult stage, the largest individuals (62 males and 43 females) were selected and sectioned at Gosner stage 42. Males and females were separated using the gross morphology of the gonads under the dissecting microscope. Testes were shorter than the ovaries. Testes were characterized by medullary development and distinct testicular lobes, while ovaries were characterized by cortical development with a central ovarian cavity surrounded by a ring of connective tissue (Hayes et al., 2006). Except for the lower concentration of diazinon $(0.375 \mathrm{ppb})$, all the other insecticide-exposed males developed multiple oocytes surrounded by spermatozoa and somatic tissue (Figure 3). None of the females or males in the control group had any abnormalities in their gonads.

\section{DISCUSSION}

Chronic exposure to field level of three insecticides showed a significant reduction in the survival of tadpoles of $P$. cruciger. Insecticides also affected the growth of the tadpoles where the exposed individuals were smaller and took a longer time to metamorphose. However, none of the chemicals induced any external malformations in $P$. cruciger. The spraying concentration of diazinon is $1000 \mathrm{mg} / \mathrm{L}$ and the field concentration of diazinon was about $1.5 \mathrm{ppb}$ (Insecticide Registrar Office, Peradeniya). Sumanadasa et al. in 2008 studied the effects of diazinon on mortality and growth of larvae of two amphibians, $D$. melanostictus and P. cruciger, at Gosner stages 20 - 22 for seven days. Their results showed that exposure to $10 \mathrm{mg} / \mathrm{L}$ of diazinon caused significant elevations in larval mortality in both species and exposed tadpoles experienced growth retardation where the tadpoles being significantly smaller (Sumanadasa et al., 2008). Although these concentrations were higher than field levels, short-term exposure to such levels is possible since the spraying concentration is high. However, we used much lower concentrations of $0.375,0.750,1.5$, and $3.0 \mathrm{ppb}$ and even at these levels, the survival was significantly reduced to $60 \%, 48 \%, 30 \%$, and $27 \%$, respectively. Earlier, Diazinon was one of the most extensively used household insecticides in the U. S. as well as in agricultural pest control. After 2000, however, all indoor usage was reduced and by 2005 outdoor residential uses of diazinon was terminated. Garber et al. (2007) reported the direct and indirect effects of diazinon on the critically endangered California Red-legged Frog (Rana aurora draytonii) in agricultural and non-agricultural sites. Diazinon was detected in the volatilization, runoff, spray drift, atmospheric transport, and subsequent deposition, eventually reaching the aquatic and terrestrial habitats of the California red-legged frog and its prey.

All three test chemicals induced the development of testicular oocytes in male frogs of P. cruciger and affected the survival and growth of the tadpoles. Among the gonadal anomalies, testicular oocytes are the most commonly observed at the histological level among fish and amphibians, known as "rudimentary hermaphroditism" (Jobling et al., 1998; Hecker et al., 2002). Male frogs with this condition can produce 17Beta estradiol from testicular oocytes (Hayes et al., 2003). Out of the three chemicals, the effect of carbosulfan on testicular oocyte development was more profound, where $100 \%$ of males in three concentrations and $75 \%$ in the lowest concentration developed oocytes. Carbosulfan is a carbamate and is known to affect the endocrine hormones in the serum of many organisms and humans. Male Sprague-Dawley rats exposed to carbosulfan showed $88 \%$ decrease in testosterone levels (Goad et al., 2004). Another study on semen analyses of male New Zealand rabbits indicated significant declines in ejaculate 
volume, sperm motility, concentration, and total output, and fructose content upon carbosulfan exposure (El-Zarkouny et al., 1999). Moreover, they reported a that carbosulfan significantly lowers the level of serum testosterone in the exposed animals, increases in the number of abnormal and dead spermatozoa, sperm without acrosomes and spermatozoal methylene-blue reduction time (El-Zarkouny et al., 1999). They found that there is an increase number of sperms with abnormal head morphology after exposure.

Profenofos also induced testicular oocytes in $P$. cruciger. The endocrine disruptive ability of profenofos has been studied in many animals, including humans. A study conducted on the rabbit to test the effect of profenofos on the testes showed a reduction in body weight, reduction in the weight of the testes, and the histopathological observations showed that disappearance of Leydig's cells and abnormal growths in seminiferous tubules (Memon et al., 2014). Profenofos has effects on male-specific cytochrome P450 (CYP) enzymes in adult Wistar rats as it down-regulates the levels of hepatic and testicular CYP2C11 and CYP3A2 mRNA and protein expression (Moustafa et al., 2008). They further showed that overall profenofos acts as an endocrine disruptor of male-specific CYP enzymes and affects testosterone concentration. Zidan, (2009) exposed rats to profenofos and reported that the exposed rats have decreased testes weight, sperm counts, sperm motility and morphologically abnormal spermatozoa. Besides, histopathological examination of the testes also showed destruction and degeneration, in a layer of columnar epithelium, edematous changes surrounding the seminiferous tubules besides vacuolated spermatogonial cells and longer Leydig cells (Moustafa et al., 2007). Recently, Memon et al. (2015) showed that in humans, profenofos inhibits serum testosterone synthesis by disrupting the hypothalamic, pituitary-testicular axis, and this could impair the reproductive function in spray workers. However, Orton et al. (2011) reported that profenofos was not identified as having anti-androgenic properties.

Diazinon also induced testicular oocytes in $P$. cruciger. It has been shown in humans that an association between poor semen quality and high levels of alachlor, diazinon, atrazine, metolachlor and 2, 4-D (2, 4-dichlorophenoxyacetic acid) suggesting that insecticide residues as a possible factor for the decreased in semen quality observed between rural and urban areas in the USA (Swan et al., 2003). Diazinon affects the structure of testis and levels of sex hormones in adult male mice (Fattahi et al., 2009). This study reported a reduction in reduction in sperm counts, spermatogenic, diameter and weight of testes, Leydig and Sertoli cells and a decrease in serum testosterone concentration. Further, testis showed histopathological changes in the seminiferous tubules and increased levels of LH and FSH (Fattahi et al., 2009). Although the toxicity to diazinon was not as high as profenofos, diazinon has been listed as one of the highly toxic chemicals to fish and aquatic invertebrates (EPA, 2006). Aquatic invertebrate $\mathrm{LC}_{50} 0.079 \mathrm{ppm}$ for bluegill sunfish, $0.635 \mathrm{ppm}$ for rainbow trout and $0.522 \mathrm{ppb}$ for
Daphnia sp. Acute toxicity of diazinon to amphibians indicates less sensitivity than fish $\left(96 \mathrm{~h} \mathrm{LC}_{50}=7500 \mu \mathrm{g} / \mathrm{L}\right.$ in yellow-legged frog; EPA, 2006). However, the metabolite diazoxon is more toxic than diazinon $\left(96 \mathrm{~h} \mathrm{LC}_{50}=760\right.$ $\mu \mathrm{g} / \mathrm{L}$ ). The $\mathrm{LD}_{50}$ for terrestrial phase bullfrogs (Rana catesbiana) was found to be $>2000 \mathrm{mg} / \mathrm{kg}$ (EPA, 2006). Carbosulfan showed the least toxicity to $P$. cruciger. The estimated median lethal concentration $\left(\mathrm{LC}_{50}\right)$ and median ChE inhibitory concentration $\left(\mathrm{IC}_{50}\right)$ in, D. melanostictus for $96 \mathrm{~h}$ were 24 and $2.1 \mathrm{mg} / \mathrm{L}$ carbosulfan respectively (Samarakoon and Pathiratne, 2017) 48 h, 72 h, and 96 has $28.5,25.9$, and $24.0 \mathrm{ppm}$ respectively. The median lethal concentration of carbosulfan for freshwater fish Labeo rohita is $1.2 \mathrm{mg} / \mathrm{L}$ at 96 exposure period (Nagaraju and Rathnamma, 2014). Acute toxicity or the $\mathrm{LC}_{50}$ of an organism varies depending on the chemical. Jayawardena et al. (2010) reported the $\mathrm{LC}_{50}$ of chlorpyrifos, dimethoate, glyphosate, and propanil to the tadpoles of $P$. cruciger at Gosner stage 25 - 26, having a wide range of 1.21, 8.40, 14.99 , and $2.21 \mathrm{ppm}$, respectively when exposed for 48 h. The $\mathrm{LC}_{50}$ values profenofos, diazinon, and carbosulfan of $P$. cruciger at the same Gosner stage (25 - 26) exposed for the same duration ( $48 \mathrm{~h}$ ) have a similar range of 1.29 , 10.33 , and $18.17 \mathrm{ppm}$.

Studies in humans and animals support the role of environmental contaminants as potential endocrine disruptors. They mimick natural hormones such as estrogen and testosterone and interact with the endocrine system and exert toxic effects. The environmental toxicants interacts with steroid receptors in the testis and thereby interfering with proliferation and differentiation of spermatogenic cells (Saradha and Mathur, 2006). In utero exposures to several antiandrogenic compounds exhibit malformations in the epididymis and vas deferens.

All three chemicals tested in the present study are widely applied in the rice fields in Sri Lanka. Rice fields, unlike other freshwater ecosystems where insecticide runoff is found, are subjected to direct application of the chemicals and the water should be kept standing in the field throughout the growth period. Therefore, the levels of these chemicals are expected to be much higher, especially in water scarcity areas. As many as 18 amphibian species including . cruciger inhabit rice fields throughout Sri Lanka (Bambaradeniya, 2000). Mortality has direct implications on population declines, but a reduced growth rate may have indirect consequences. Commonly used agricultural insecticides such as chlorpyrifos, dimethoate, glyphosate, propanil, and profenofos have been tested on two local amphibian species: the common hourglass tree frog $P$. cruciger and the Asian common toad Bufo melanostictus and shown that all the chemicals significantly decreased survival, affected the growth and induced malformations under laboratory conditions (Jayawardena et al., 2010, 2011; Ratnayake and Rajakaruna, 2018). Today, the use of all these chemicals except profenofos is banned in Sri Lanka. First, in 2008, a 3-year phased import ban of dimethoate was announced due to its pivotal role in selfharming leading to suicides in Sri Lanka (Pearson et al., 2013; Knipe et al., 2017). Later, glyphosate was banned in 
2015 after the theory was put forward that it was responsible for chronic kidney disease of unknown etiology (CKDu) in most rice-growing areas in the country. However, this ban is now relaxed for tea growers as there were no records of $\mathrm{CKDu}$ in the tea plantation areas.

Understanding and predicting the impacts of agrochemicals on non-target organisms is quite challenging. As sensitive bioindicators, mphibians are good models for evaluating the ecotoxicological effects, especially in agricultural lands, where insecticide application is high (Relyea and Hoverman, 2006).

\section{CONCLUSION}

The three insecticides, profenofos, diazinon, and carbosulfan induced the development of testicular oocytes in male frogs of $P$. cruciger, mortality. They affected the growth of the tadpoles exposed to ecologically relevant concentrations of the chemicals under laboratory conditions. However, none of the chemicals induced any external malformations. The acute toxicity in terms of $\mathrm{LC}_{50}$ was highest in profenofos.

\section{ACKNOWLEDGEMENT}

The authors acknowledge the National Science Foundation Sri Lanka (Grant no. RG/2014/EB/02) for financial support and Varuni Imbuldeniya for technical assistance.

\section{DECLARATION OF CONFLICT OF INTEREST}

The authors declare that there is no conflict of interest.

\section{REFERENCES}

Annamalai, J. and Namasivaya, M.V. (2015). Endocrinedisrupting chemicals in the atmosphere: their effects on humans and wildlife. Environment International 76: 78-97. DOI: 10.1016/j.envint.2014.12.006.

Bambaradeniya, C.N.B. (2000). Ecology and biodiversity in an irrigated rice field ecosystem in Sri Lanka. Ph.D. thesis, University of Peradeniya, Peradeniya.

Bernabò, I., Gallo, L., Sperone, E., Tripepi, S. and Brunelli, E. (2011). Survival, development, and gonadal differentiation in Rana dalmatina chronically exposed to chlorpyrifos. Journal of Experimental Zoology Part A: Ecological Genetics and Physiology 315A: 314327. DOI: https://doi.org/10.1002/jez.678.

Carr, J.A., Gentles, A., Smith, E.E., Goleman, W.L., Urquidi, L.J., Thuett, K., Kendall, R.J., Giesy, J.P., Gross, T.S., Solomon, K.R. and Van Der Kraak, G. (2003). Response of larval Xenopus laevis to atrazine: assessment of growth, metamorphosis, and gonadal and laryngeal morphology. Environmental Toxicology and Chemistry 22(2): 396-405.

El-Zarkouny, S.A., Ayoub, M.A., Ishak, M.H.G., El-Nouty, F.D., Hassan, G.A., Abo EL-EZZ, Z.R. and Salem, M.H. (1999). Effect of carbosulfan pesticide and selenium on some semen characteristics and serum testosterone in male rabbits. International Journal of Environmental Health Research 9(2): 117-124.

EPA (2006) Reregistration Eligibility Decision (RED) Diazinon; EPA 738-R-04-006; U.S. Environmental Protection Agency, Office of Prevention, Pesticides and
Toxic Substances, Office of Pesticide Programs, U.S. Government Printing Office: Washington, DC, 2006.

Fan, W., Yanase, T., Morinaga, H., Gondo, S., Okabe, T., Nomura, M., Komatsu, T., Morohashi, K.I., Hayes, T.B., Takayanagi, R. and Nawata, H. (2007). Atrazineinduced aromatase expression is SF-1 dependent: implications for endocrine disruption in wildlife and reproductive cancers in humans. Environmental Health Perspectives 115(5): 720.

Fattahi, E., Parivar, K. and Jorsaraei, S.G.A. (2009). The effects of diazinon on testosterone, FSH and LH levels and testicular tissue in mice. International Journal of Reproductive Bio Medicine 7(2): 59-64.

Garber, K., Jones, R.D. and Steeger, T. (2007). Risks of carbaryl use to the federally-listed California redlegged frog (Rana aurora draytonii). Pesticide effects determination. Environmental Fate and Effects Division, US Environmental Protection Agency Office of Pesticide Programs, Washington, DC.

Giri, S., Giri, A., Sharma, G.D. and Prasad, S.B. (2002). Mutagenic effects of carbosulfan, a carbamate pesticide. Mutation Research/Genetic Toxicology and Environmental Mutagenesis 519(1-2): 75-82. DOI: 10.1016/s1383-5718(02)00114-6.

Goad, R.T., Goad, J.T., Atieh, B.H. and Gupta, R.C. (2004). Carbofuran-induced endocrine disruption in adult male rats. Toxicology Mechanisms and Methods 14(4): 233-239.

Gosner, K.L. (1960). A simplified table for staging anuran embryos and larvae with notes on identification. Herpetologica 16(3): 183-190.

Griffing, A.H., Bowerman, I. and Sessions, S.K. (2017). Histology reveals testicular oocytes and trematode cysts in the threatened Oregon spotted frog ("Rana pretiosa") Northwestern Naturalist 98(1): 24-32.

Grube, A., Donaldson, D., Kiely, T. and Wu, L. (2011). Pesticides industry sales and usage. US EPA, Washington, DC.

Hayes, T.B., Collins, A., Lee, M., Mendoza, M., Noriega, N., Stuart, A.A. and Vonk, A. (2002a). Hermaphroditic, demasculinized frogs after exposure to the herbicide atrazine at low ecologically relevant doses. Proceedings of the National Academy of Sciences 99(8): 5476-5480. DOI: https://doi.org/10.1073/pnas.082121499.

Hayes, T.B., Haston, K., Tsui, M., Hoang, A., Haeffele, C. and Vonk, A. (2002b). Feminization of male frogs in the wild. Water-borne herbicide threatens amphibian populations in parts of the United States. Nature 419: 895-896. DOI: https://doi.org/10.1038/419895a.

Hayes, T., Haston, K., Tsui, M., Hoang, A., Haeffele, C. and Vonk, A. (2003). Atrazine-induced hermaphroditism at $0.1 \mathrm{ppb}$ in American leopard frogs (Rana pipiens): laboratory and field evidence. Environmental Health Perspectives 111(4): 568-575.

Hayes, T.B., Stuart, A.A., Mendoza, M., Collins, A., Noriega, N., Vonk, A., Johnston, G., Liu, R. and Kpodzo, D. (2006). Characterization of atrazineinduced gonadal malformations in African clawed frogs (Xenopus laevis) and comparisons with effects of an androgen antagonist (cyproterone acetate) 
and exogenous estrogen (17 beta-estradiol): support for the demasculinization/feminization hypothesis. Environmental Health Perspectives 114(sup 1): 134141.

Hayes, T.B. (2004). There is no denying this: defusing the confusion about atrazine. American Institute of Biological Sciences Bulletin 54(12): 1138-1149.

Hayes, T.B. (2005). Welcome to the Revolution: integrative biology and assessing the impact of endocrine disruptors on environmental and public health1. Integrative and Comparative Biology 45(2): 321-329.

Hayes, T.B., Khoury, V., Narayan, A., Nazir, M., Park, A., Brown, T., Adame, L., Chan, E., Buchholz, D., Stueve, T. and Gallipeau, S. (2010). Atrazine induces complete feminization and chemical castration in male African clawed frogs (Xenopus laevis). Proceedings of the National Academy of Sciences 107(10): 4612-4617. DOI: https://doi.org/10.1073/pnas.0909519107.

Hecker, M., Murphy, M.B., Coady, K.K., Villeneuve, D.L., Jones, P.D., Carr, J.A., Solomon, K.R., Smith, E.E., Van Der Kraak, G., Gross, T. and Du Preez, L. (2006). Terminology of gonadal anomalies in fish and amphibians resulting from chemical exposures. Reviews of Environmental Contamination and Toxicology 187: 103-131.

Hecker, M., Park, J.W., Murphy, M.B., Jones, P.D., Solomon, K.R., Van Der Kraak, G., Carr, J.A., Smith, E.E., du Preez, L., Kendall, R.J. and Giesy, J.P. (2005). Effects of atrazine on CYP19 gene expression and aromatase activity in testes and on plasma sex steroid concentrations of male African clawed frogs (Xenopus laevis). Toxicological Sciences 86(2): 273-280.

Hecker, M., Tyler, C.R., Hoffmann, M., Maddix, S. and Karbe, L. (2002). Plasma biomarkers in fish provide evidence for endocrine modulation in the Elbe River, Germany. Environmental Science and Technology 36(11): 2311-2321.

IUCN. (2004). Red list of threatened species. Available from: http://www. iucn red list.org/info/categories criteria 2001. Html/ (15 June 2014).

Jayawardena, U.A., Navaratne,A.N.,Amerasinghe, P.H. and Rajakaruna, R.S. (2011). Acute and chronic toxicity of four commonly used agricultural pesticides on the Asian common toad, Bufo melanostictus Schneider. Journal of the National Science Foundation of Sri Lanka 39(3): 267-276. DOI: http://doi.org/10.4038/jnsfsr.v39i3.3631.

Jayawardena, U.A., Rajakaruna, R.S., Navaratne, A.N. and Amerasinghe, P.H. (2010). Toxicity of agrochemicals to common hourglass tree frog (Polypedates cruciger) in acute and chronic exposure. International Journal of Agriculture and Biology 12(5): 641-648.

Jobling, S., Nolan, M., Tyler, C.R., Brighty, G. and Sumpter, J.P. (1998). Wide spread sexual disruption in wild fish. Environmental Science and Technology 32(17): 2498-2506.

Kloas, W., Lutz, I., Urbatzka, R., Springer, T., Krueger, H., Wolf, J., Holden, L. and Hosmer, A. (2009). Does atrazine affect larval development and sexual differentiation of South African clawed frogs? Annals of the New York Academy of Sciences 1163(1): 437-440.

Knipe, D.W., Chang, S.S., Dawson, A., Eddleston, M.,
Konradsen, F., Metcalfe, C. and Gunnell, D. (2017). Suicide prevention through means restriction: impact of the 2008-2011 pesticide restrictions on suicide in Sri Lanka. Plos ONE 12(3): 1-12. DOI: https://doi.org/10.1371/journal.pone.0172893.

Li, X., Li, S., Liu, S. and Zhu, G. (2010). Lethal effect and in vivo genotoxicity of profenofos to Chinese native amphibian (Rana spinosa) tadpoles. Archives of Environmental Contamination and Toxicology 59(3): 478-483.

Lifshitz, N. and St Clair, C.C. (2016). Coloured ornamental traits could be effective and non-invasive indicators of pollution exposure for wildlife. Conservation Physiology 4(1):1-16. DOI: https://doi.org/10.1093/ conphys/cow028.

Manamendra-Arachci, K. and Dutta, S.K. (1996). The Amphibian Fauna of Sri Lanka. Wildlife Heritage Trust of Sri Lanka, Colombo, Sri Lanka.

McCoy, K.A., Bortnick, L.J., Campbell, C.M., Hamlin, H.J., Guillette Jr, L.J. and Mary, C.M.S. (2008). Agriculture alters gonadal form and function in the toad Bufo marinus. Environmental Health Perspectives 116(11): 1526.

McDaniel, T.V., Martin, P.A., Struger, J., Sherry, J., Marvin, C.H., McMaster, M.E., Clarence, S. and Tetreault, G. (2008). Potential endocrine disruption of sexual development in free ranging male northern leopard frogs (Rana pipiens) and green frogs (Rana clamitans) from areas of intensive row crop agriculture. Aquatic Toxicology 88(4): 230-242.

Memon, S.A, Memon, N., Shaikh, S.A., Butt, Z. and Mal, B. (2015). Assessment of profenofos exposure an endocrine disrupting chemical in relation with serum testosterone alterations. Pure and Applied Biology 4(1): 1.

Memon, S.A., Shaikh, S.A. and Memon, N. (2014). Effects of profenofos an endocrine disrupting chemical on leydig's cells in rabbits. Journal of Animal and Plant Sciences 24(1): 167-171.

Moustafa, G.G., Ibrahim, Z.S., Hashimoto, Y., Alkelch, M., Kentaro, Q., SakamotoIshizuka, M. and Fujita, S. (2007). Testicular toxicity of profenofos in matured male rats. Archives of Toxicology 81: 875-881. DOI: https://doi.org/10.1007/s00204-007-0217-2.

Moustafa, G.G., Ibrahim, Z.S., Ahmed, M.M., Ghoneim, M.H., Sakamoto, K.Q., Ishizuka, M. and Fujita, S. (2008). Down regulation of male-specific cytochrome P450 by profenofos. Japanese Journal of Veterinary Research 56(2): 109-118.

Murphy, M.B., Hecker, M., Coady, K.K., Tompsett, A.R., Jones, P.D., Du Preez, L.H., Everson, G.J., Solomon, K.R., Carr, J.A., Smith, E.E. and Kendall, R.J. (2006). Atrazine concentrations, gonadal gross morphology and histology in ranid frogs collected in Michigan agricultural areas. Aquatic Toxicology 76(3-4): 230245. DOI: 10.1016/j.aquatox.2005.09.010.

Nagaraju, B. and Rathnamma, V.V. (2014). Gas liquid chromatography-flame ionization detector (GLC-FID) residue analysis of carbamate pesticide in freshwater fish Labeo rohita. Toxicology Research 3(3): 177-183.

Orton, F., Carr, J.A. and Handy, R.D. (2006). Effects of 
nitrate and atrazine on larval development and sexual differentiation in the northern leopard frog Rana pipiens. Environmental Toxicology and Chemistry 25(1): 65-71.

Orton, F., Rosivatz, E., Scholze, M. and Kortenkamp, A. (2011). Widely used pesticides with previously unknown endocrine activity revealed as in vitro antiandrogens. Environmental Health Perspectives 119(6): 794-800. DOI: 10.1289/ehp.1002895.

Pearson, M., Zwi, A.B., Buckley, N.A., Manuweera, G., Fernando, R. and Dawson, A.H. (2013). Policymaking 'under the radar': a case study of pesticide regulation to prevent intentional poisoning in Sri Lanka. Health Policy Plan.

Ratnayake, Y. and Rajakaruna, R.S. (2018) Cocktail effect of Profenophos and Abamectin on tadpoles of Asian Common Toad (Duttaphrynus melanostictus) Ceylon Journal of Science 47(2): 185-194. DOI: http://doi. org/10.4038/cjs.v47i2.7515.

Relyea, R. and Hoverman, J. (2006). Assessing the ecology in ecotoxicology: a review and synthesis in freshwater systems. Ecology Letters 9(10): 1157-1171.

Rohr, J.R. and McCoy, K.A. (2010). A qualitative metaanalysis reveals consistent effects of atrazine on freshwater fish and amphibians. Environmental Health Perspectives 118(1): 20-32. DOI: 10.1289/ ehp.0901164.

Saradha, B. and Mathur, P.P. (2006). Effect of environmental contaminants on male reproduction. Environmental Toxicology and Pharmacology 21(1): 34-41. DOI: 10.1016/j.etap.2005.06.004.

Schwindt, A.R. (2015). Parental effects of endocrinedisrupting compounds in aquatic wildlife: is there evidence of transgenerational inheritance? General and Comparative Endocrinology. 219: 152-164. DOI: 10.1016/j.ygcen.2015.01.020.
Skelly, D.K., Bolden, S.R. and Dion, K.B. (2010). Intersex frogs concentrated in suburban and urban landscapes. EcoHealth 7(3): 374-379.

Smith, E.E., Du Preez, L.H., Gentles, A., Solomon, K.R., Tandler, B., Carr, J.A., Van Der Kraak, G.L., Kendall, R.J., Giesy, J.P. and Gross, T.S. (2005). Assessment of laryngeal muscle and testicular cell types in Xenopus laevis (Anura Pipidae) inhabiting maize and non-maize growing areas of South Africa. African Journal of Herpetology 54(1): 69-76.

Solomon, K.R., Carr, J.A., Du Preez, L.H., Giesy, J.P., Kendall, R. J., Smith, E.E. and Van Der Kraak, G.J. (2008). Effects of atrazine on fish, amphibians, and aquatic reptiles: a critical review. Critical Reviews in Toxicology 38(9): 721-772.

Sumanadasa, D.M., Wijesinghe. M.R. and Ratnasooriya, W.D. (2008). Effects of diazinon on larvae of the Asian common toad (Bufo melanostictus, Schneider 1799). Environmental Toxicology and Chemistry 27(11): 2320-2325.

Swan, S.H., Brazil, C., Drobnis, E.Z., Liu, F., Kruse, R.L., Hatch, M., Redmon, J.B., Wang, C. and Overstreet, J.W. (2003). Geographic differences in semen quality of fertile US males. Environmental Health Perspectives 111(4): 414-420.

Tavera-Mendoza, L., Ruby, S., Brousseau, P., Fournier, M., Cyr, D. and Marcogliese, D. (2002). Response of the amphibian tadpole (Xenopus laevis) to atrazine during sexual differentiation of the testis. Environmental Toxicology and Chemistry 21(3): 527-531.

Zidan, N.A. (2009). Evaluation of the reproductive toxicity of chlorpyrifos methyl, diazinon and profenofos pesticides in male rats. International Journal of Pharmacology 5(1): 51-57. 